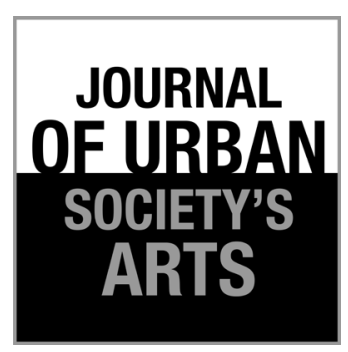

Volume 6 Nomor 2,

Oktober 2019: 123-127

\title{
The Study of "Batik" Application on The Partition of Office Interior
}

Tunjung Atmadi, Rizky Dinata, and Ali Ramadhan

Program Studi Desain Interior, Fakultas Desain dan Seni Kreatif

Universitas Mercu Buana.

Jl. Meruya Selatan Kembangan, West Jakarta, Jakarta - 1165

E-mail: tunjung.atmadi@mercubuana.ac.id

\begin{abstract}
ABSTRAK
Kajian Aplikasi "Batik" Pada Partisi Interior Kantor. Partisi adalah bagian dari furniture kantor yang sangat berfungsi sebagai pembatas ruang. Partisi membantu memberikan solusi untuk menata ruang kerja di kantor agar semakin rapi dan efisien. Penggunaan partisi merupakan suatu konsep dalam memaksimalkan area kantor agar lebih nyaman. Dengan sistem knock down dinding panel partisi dapat dibongkar dan dipasang kembali untuk dipasang atau diaplikasi dengan kain batik pola tertentu. Interior kantor saat ini menjadi bagian penting sebagai representasi terhadap klien untuk menambah performa penampilan sebuah kantor. Metode yang digunakan pada penelitian ini adalah metode deskriptif kualitatif, dimulai dari konsep awal produk, pengembangan produk dan prototype aplikasi desain motif batik pada partisi tersebut. Hasil dari kajian ini diharapkan dapat melengkapi citra ruang dengan gaya tertentu sebagai elemen pendukung desain interior, juga menambah penampilan interior kantor tersebut menjadi lebih dinamis dan dapat meningkatkan produktifitas kerja.
\end{abstract}

Kata kunci: batik partisi; mega mendung; kawung

\begin{abstract}
Office partitions are part of office furniture that serves as a divider of office space. Office partitions provide solutions to organize workspace in the office to make it more tidy and efficient. The use of office partition is a modern concept of office space in maximizing office space to make it more comfortable. By applying the knockdown system to the office partition, wall panels can be dismantled and installed back to be fixed or applied with specific batik pattern. The office interior now became an important part to represent clients to increase the look of an office. The method used in this research is a descriptive qualitative method, starting from the initial concept of the product, product development and prototype application of batik motif design on the partition. The results of this study are expected to be able to complement the space image with a specific style as a supporting element of interior design, as well as add to the appearance of the office interior to be more dynamic and increase working productivity.
\end{abstract}

Keywords: batik partitions; mega mendung; kawung

\section{Introduction}

Based on its function as a room divider, then a partition is needed to organize the interior design of the office. By providing a partition in the workspace in the office, psychologically the partition will present a sense of comfort and protection when carrying out these activities. The development of interior design trends has resulted in increasingly diverse forms, types, and partition materials. Interior design is the process of forming a space experience, comfortable atmosphere, formal, sacred, relaxed, familiar, etc. can be formed by giving special treatment to the spatial elements 
such as the partition (Ramadhan, 2019). The atmosphere that we want can be realized by selecting the appropriate material on the partition with the right finishing.

In the interior design the meaning of the partition is a flexible room divider, where the one room with another has a different function. In addition to this, the partition can also function as a decorative accent to conceptualize the interior as a partition wall panel office workspace, so that its presence can make the impression of a living room. For a neat and modern arrangement of office space, now a good office partition is needed, this partition will make the workspace more comfortable and neat. Apart from the aesthetic function, office partitions are always made knockdown with the use of materials such as MDF, fabric and glass. This office partition has developed to be conventional in many offices, some partitions are made with a portable design, making it easy to move, move or replace the wall panels.

Currently, many offices apply the concept of modern style interior design, a design style that is simple, clean, functional, stylish and always follows the development of the times associated with the developing modern lifestyle. In designing concepts and styles always look at the value of objects (furniture) based on the size of the function and its suitability to lifestyles that demand fast-paced, easy and functional. In the interior, modern lifestyle impacts on the desire to have a simple, clean and functional room, as a symbol of modern spirit. In the modern-style interior concept, a piece of batik cloth is an alternative to give a charming touch and focus of interest in an interior room. Batik in the appearance of interior design has a classic and ethnic impression, the combination of batik motifs with modern interior elements appears proportionally. Related to local wisdom, batik application is now a breakthrough in office interior design. Batik is flexible enough to be applied to office interior designs in this case office partitions, both contemporary and traditional.

\section{Design Concept}

The concept of design is the rationale of the designer in his efforts to solve the demands of the design and design problems. Understanding the concept according to Peorwadarminta comes from the Latin word that is Conseptus which means catch. So the concept is the result of human capture or translation, when faced with a demand. Another meaning of the concept of interior design is how to arrange objects that surround us in the room can create an atmosphere of peace and calm, coolness, romance or whatever is desired.

The main object in interior design is furniture, and other supporting objects such as batik cloth, curtains, wallpapers, etc. are a complement that will perfect the overall design so that they form a linkage with each other on each object in the room, and will display nuances in accordance with the design room interior.

According to D.K. Ching, interior design is to plan, organize and design interior spaces in buildings. The physical order above can meet our basic needs for means to shelter and take shelter, determine the steps as well as regulate the form of activity, maintain aspirations and express ideas that accompany all actions, affect appearance, feelings and personality. Therefore, the intent and purpose of interior designers is to improve function

The layout of a business space by the owner is designed in such a way as to a specific purpose or purpose. The layout is made as well as possible so that visitors who come feel at home and make their own impression. People who inhabit or see the space can judge according to his own taste. The shape, the outermost, and the interior arrangement of a room determine the impression that arises (Wilkening, 2002).

\section{Batik and its Application}

Batik (or the word Batik) comes from the Javanese language "amba" which means writing and "nitik". Batik is the art of painting done on fabric using wax or wax as a protector to get the decoration on the fabric.

Understanding batik in general is the formation of images on the fabric using the dyeing technique by using wax or wax as a barrier and dye on the fabric. (Warsito, 2008) 
Batik is a work that is exposed on a flat area (cloth or silk) by painting or writing, brushed or spilled or by using a canting or stamp by using the night to cover it to keep its original color. Search for the meaning of the word batik in the Javanese term comes from the word "rambating" point or series of dots. (Honggopuro, 2002)

The development of batik techniques and applications has become a breakthrough in interior design. As a textile product, batik is also used as other disposable items for interior decoration such as wall displays, room dividers. Along with the support of today's technology, its application is now growing rapidly and innovatively. With its beauty, batik can indeed be a charming interior decoration element to be presented at the office. Through proper placement, batik motifs can give 'color' to an office workspace. Batik is flexible enough to be applied to office interior designs, both in modern, contemporary and classic styles. The application of batik touches in office interior partitions will not only give a refresher, but will also present an ethnic impression. For the arrangement of office space now needed a good office partition. Office partitions will make work space more comfortable and neat. The combination of color and height on the partition can be adjusted to the needs of the office space and office interior design. In addition to the aesthetic function, office partitions can also make the room neater than telephone cables or electrical cables because the panels inside the partitions have cable space. Because office partitions are always made with a knockdown system that can reach heights and the use of materials that can be chosen starting from full fabric, half glass and full glass.

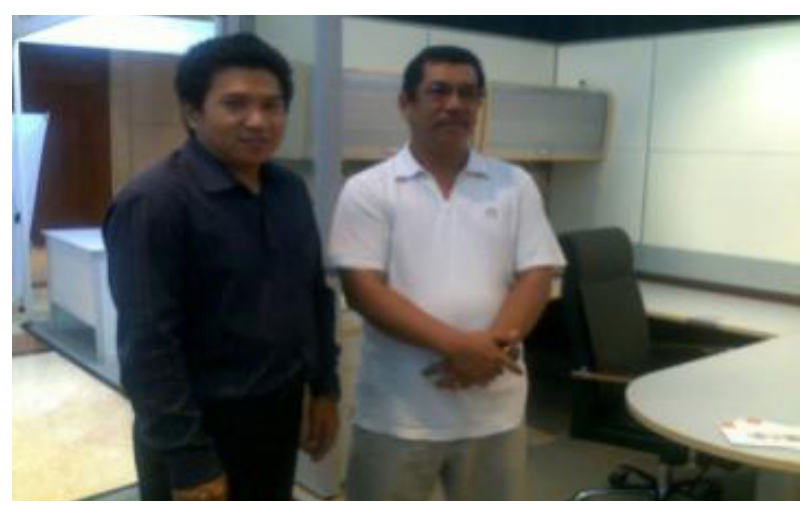

Figure 1. Researchers with the CEO of PT. Reafo at JCC.

\section{Some Batik Applications on Office Partition}

\section{a. Batik Kawung on Partition}

The study conducted by the writer with this kawung batik motif as a design on the office partition panel because in addition to this kawung pattern has a deep philosophy, the simplicity of the kawung batik motif in its application is the easiest to apply to the partition panel. Kawung motif originates from a cross section of palm fruit, commonly known as kolang kaling, which is oval in Javanese called kawung. The oval section is arranged diagonally lined centrally and symmetrically to form an optical illusion as if a flower has four petals. Sweet sugar palm, the tree which is perpendicular to the branch gives the value of greatness, justice and wisdom to the Kawung motif.

\section{b. Batik Mega Mendung on the Counter of Reception Table}

The working station partition panel with batik motifs in Kawung is combined with natural HPL nuances / wood fiber gives the impression of classy, luxurious, but ethnic and comfortable in the workspace. In addition, the modern design makes the atmosphere of the workspace more comfortable and orderly.

The reception desk counter with mega mendung batik pattern partition wall is applied to a partition panel that is coated with natural patterned HPL wood fiber sungkai with a list of aluminum powder coating in gray. The reception

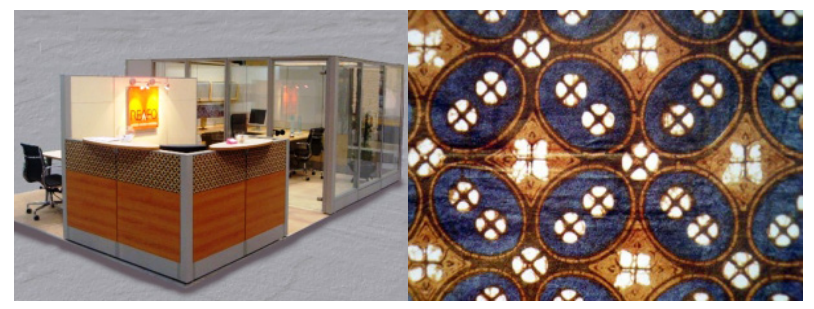

Figure 2. Application of batik on the partitions.

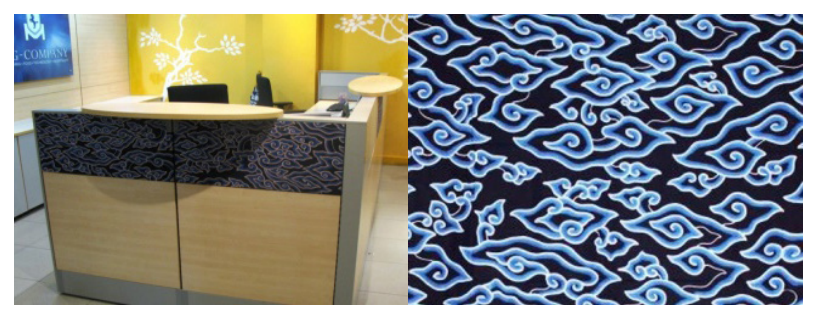

Figure 3. Mega Mendung batik application on the table. 
counter desk itself is a form of service to get information for guests and employees.

\section{c. Batik Mega Mendung on the Work Station Partition}

Room dividers, or better known as partitions, are interior elements which is very important to emphasize the function of space. The use of separator dividers will reinforce the function of each space. Besides that, the partition also allows users of the room to have privacy when guests come to visit, even though they are in one room. Workspace with a wall covering/ partition panel patterned mega cloudy batik. The touch of batik motifs on the panel stand out among the other elements that are plain and not so crowded making the modern impression stronger and more lively. The color of the wall cover used in each of these rooms still uses the basic color of the atmosphere of the room itself so that it can still blend perfectly. Likewise with the application of batik in the waiting room, the color is still the basic color of the room.

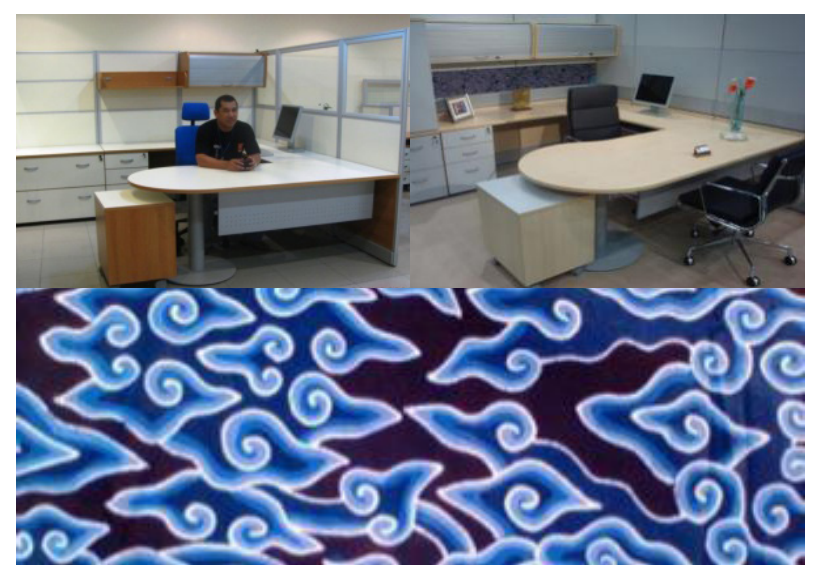

Figure 4. Working station partition panel and batik application on partition panels.

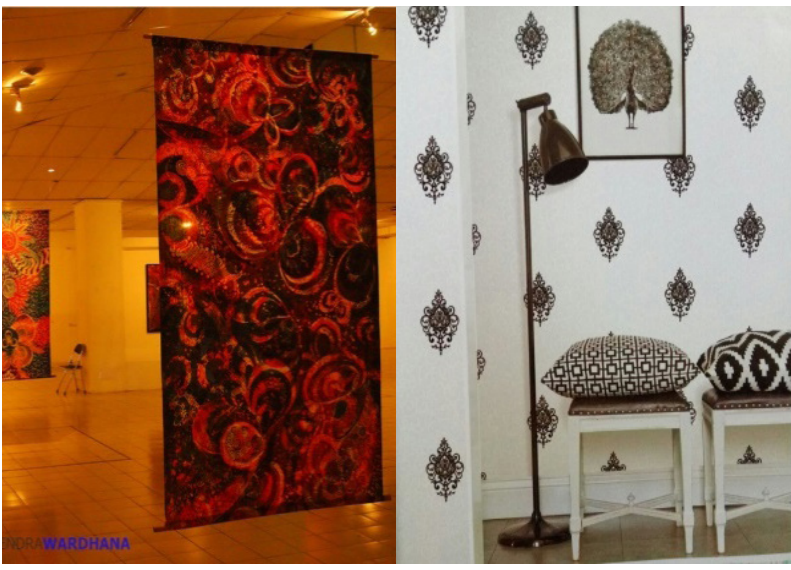

Figure 5. Batik application on partition panels.
- Wall Treatment of Batik Fabric

Batik cloth as a wall hanging on the wall with the right layout settings, can give the impression of a beautiful atmosphere of the room. The nuance will look more attractive if there is soft lighting that highlights the hanging wall. And it can be ensured that the decoration is a substitute for beautiful paintings and batik is flexible enough to be applied to interior office designs.

- Several Types of Batik That are Commonly Used for Interiors

The interior design of a partition wall or room divider is a flexible room divider. A divider that can be installed and moved as desired. Aside from being a room divider, a partition wall can also be used as a decorative accent. The type of partition wall that is designed is a partition that has a closed design but not completely. The nature of this partition wall is flexible, can be installed and moved according to the user's wishes. It needs attention when someone adapts certain motifs of batik to industrial-scale products, which requires having to understand the meaning behind that motif. It also means that there should be no meaningful motifs of aristocratic adapted for the wrong work placement.

For example, the Parang Rusak batik motif is used for the floor considering that the motif means aristocracy, even though the floor is the space that is trampled underfoot. This motif is better and fit to be used as a wall ornament for an office or hotel front office because it can image a stratum. The broken

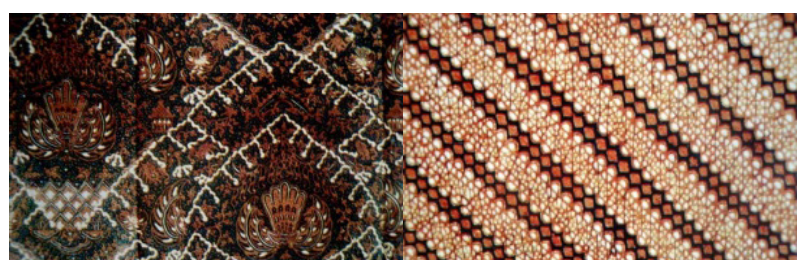

Figure 6. Cuwiri batik and Parangkusumo.

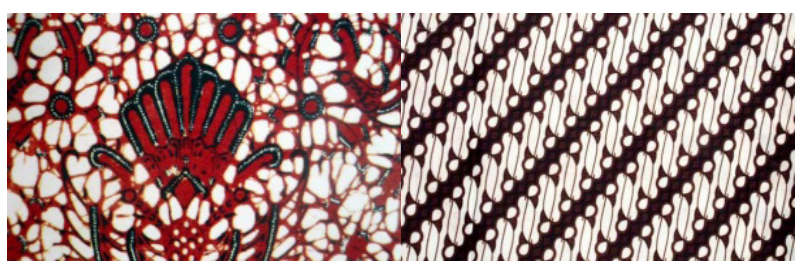

Figure 7. Batik Sidomukti and batik Parang Rusak. 
Parang motif is also not fitting to be applied to seat covers, even though it is a director's chair or a special dining room for state dinners. The more suitable motive is Sidomukti because it contains meaning about position, rank, honor and power. The content of this philosophy is very suitable for a leader.

\section{Conclusion}

A touch of batik in the world of interior design can create warmth as well as add the value. Amid the incessant minimalist-style interior which some time ago was so loved, the presence of batik patterns can be a warmer as well as an accent. And we should look at the application of batik in the interior which is no longer identical with the traditional style of space, because with a few modifications, batik can be more modern, elegant and exclusive. The development of batik motif designs refers to the elements of local wisdom combined with elements of interior design with certain styles. One form of application of batik motifs on elements of interior decoration is the walls of office partition. The application takes local wisdom elements that represent batik designs typical of certain regions,

In the interior design today, we will never lack of the idea of the existence of batik. Batik as an element of local wisdom is a legacy, very important in its application in interior design. For this reason, it needs to be developed in realizing design styles for the office interior design and other interiors application.

\section{Acknowledgements}

This research cannot be separated from a variety of outside assistance that directly and indirectly contributes to the development of writing. [Dr. Ir. Tin Budi Utami, MT] as Director and Head of Research at Mercu Buana University, [Dr. Ariani Wardhani as Dean of the Design and Creative Art faculty at Mercu Buana University] who helped provide an explanation of international journals.

\section{References}

Departemen Perdagangan. (2008). Pengembangan Ekonomi Kreatif, Departemen Perdagangan RI: Indonesia.

Alexi M. and Joanna, E. (1990). Office Space Planning: Designing for Tommorow.s Workplace, Professional Architecture, A Direction of the Mc-graw-Hill Companies.

Ching, Francis D.K. (2005). Shape architecture, Space, and Order. Jakarta: Erlangga.

Hamidin, A, S. (2010). Batik Original Cultural Heritage Indonesia. Yogyakarta: Narrative Publisher

Sian E Jay. (2007). Batik in Design Aspects. Department of Ethnography And Oriental Antiquities British Museum

Hitchcock, M .(2005). Evolusion of Batik. Direktur Internatonal for Culture, Tourism, and Development London, Metropolitan University.

Ramadhan, A and Umar, J, P. (2019). Study of Space Comfort in Street Clown Products (Case Study: Mampang Clown). Journal of Urban Society's Arts, 6(1), 24-38.

Sri Puji A. (2012). Language Batik Industry. Batik Technology University of Pekalongan

Soedarmadji JHD. (1999). Batik as Interior elements of the house. Museum Director History of Jakarta. 